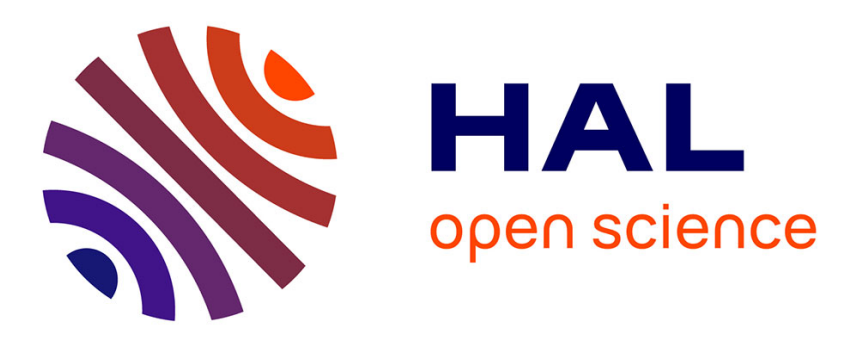

\title{
Meiofauna versus macrofauna as a food resource in a tropical intertidal mudflat
}

Pierre-Yves Pascal, Pierrick Bocher, Christel Lefrançois, Hien Duy Nguyen, Johan Chevalier, Christine Dupuy

\section{- To cite this version:}

Pierre-Yves Pascal, Pierrick Bocher, Christel Lefrançois, Hien Duy Nguyen, Johan Chevalier, et al.. Meiofauna versus macrofauna as a food resource in a tropical intertidal mudflat. Marine Biology, 2019, 166 (11), pp.144. 10.1007/s00227-019-3588-z . hal-02355875

\section{HAL Id: hal-02355875 \\ https://hal.science/hal-02355875}

Submitted on 8 Nov 2019

HAL is a multi-disciplinary open access archive for the deposit and dissemination of scientific research documents, whether they are published or not. The documents may come from teaching and research institutions in France or abroad, or from public or private research centers.
L'archive ouverte pluridisciplinaire HAL, est destinée au dépôt et à la diffusion de documents scientifiques de niveau recherche, publiés ou non, émanant des établissements d'enseignement et de recherche français ou étrangers, des laboratoires publics ou privés. 


\section{intertidal mudflat}

$8{ }^{1}$ Institut de Systématique, Evolution, Biodiversité (ISYEB) UMR 7205, Equipe Biologie de la Mangrove -

9 Université des Antilles, 97159 Pointe-à-Pitre, Guadeloupe, France

$10{ }^{2}$ Littoral, Environnement et Sociétés (LIENSs) UMR 7266 CNRS - La Rochelle University, 2 Rue Olympe de 11 Gouges, 17000, La Rochelle, France

$12{ }^{3}$ University of Science and Technology of Hanoi (USTH) - Vietnam Academy of Science and Technology 13 (VAST), 8 Hoans Quoc Viet Street, 10000 Hanoi, Viet Nam

$14 \quad{ }^{4}$ Réserve Naturelle Nationale de l’Amana, Awala-Yalimapo, French Guiana

$18 *$ Corresponding author: pierre-yves.pascal@ univ-antilles.fr 
Evaluations of the functioning of benthic marine food webs could be improved by quantifying organic matter fluxes from the meiofauna to higher trophic levels. In this study, we measured the simultaneous ingestion of meiofauna and macrofauna by common dwellers of a tropical intertidal mudflat on the coast of Amazonia. The meiofauna and macrofauna (tanaid) communities of a tropical intertidal mudflat of French Guiana were separately enriched with ${ }^{15} \mathrm{~N}$ and ${ }^{13} \mathrm{C}$, respectively. The enriched preys were then used as tracers during feeding experiments with common predators of different sizes and feeding mechanisms: a Portunidae crab (Callinectes bocourti), a Penaeidae shrimp (Farfantepenaeus subtilis) and a

31 Gobiidae fish (Gobionellus oceanicus). In feeding experiments with all predators except crabs, feeding rates increased with the availability of meiofauna and macrofauna food sources. The ability of consumers to ingest their food selectively was evaluated by calculating the differences in the ratio of macrofauna to meiofauna between the $i$ ) ingested material and ii) that available in the environment. Larger predators showed a higher degree of preferential macrofauna ingestion than smaller predators, consistent with the optimal foraging theory. For large predators, the meiofauna would be important only during early life or in the absence of large food items. 


\section{Introduction}

Marine sediments constitute one of the largest environments in the world, in terms of the area covered. They form the habitat of the meiofauna, a discrete group of small (passing through a 0.5 mm-mesh sieve), highly diverse and abundant organisms (Giere 2009). Meiofauna biomass varies considerably between habitats. It is generally smaller than that of other benthic components, but the meiofauna could plays a key role in this ecosystem, due to its high levels of production and activity (Schwinghamer et al. 1986, Moens et al. 2013). The meiofauna move through the sediment and construct burrows, thereby conveying oxygen and nutrients vertically and increasing organic matter mineralization and nutrient cycling (Aller \& Aller 1992, Coull 1999, Bonaglia et al. 2014). The meiofauna also supplies ecosystem services, such as nutrient cycling and waste processing, and it plays an important role in food webs (Schratzberger \& Ingels 2018). The meiofauna is highly diverse, with a large array of feeding strategies, resulting in the consumption of a broad spectrum of food sources, including microphytobenthos (Middelburg et al. 2000, Moens et al. 2002) and, to a lesser extent, bacteria (van Oevelen et al. 2006, Pascal et al. 2009). The meiofauna may, therefore, represents a major link between small food items and higher trophic levels (Coull 1999). The meiofauna is a high-quality food source, as the animals in this population can biosynthesize and accumulate highly unsaturated fatty acids (Fleeger 2007, Leduc et al. 2009, De Troch et al. 2012, Braeckman et al. 2015) that most metazoans are unable to produce. Numerous studies have demonstrated the importance of the meiofauna in the diet of epibenthic predators

61 (Coull 1990), such as fishes (Fitzhugh \& Fleeger 1985, Henry \& Jenkins 1995), shrimps (Bell \& Coull 1978, Nilsson et al. 1993) and crabs (Scherer \& Reise 1981). Many predators present developmental shifts in food preference, with the young preferentially ingesting meiofauna and adults preferentially ingesting larger food items (Coull 1990, 1999, Nilsson et al. 1993). 
65 The criteria governing the selection of meiofauna versus macrofauna by predators, as a

66 function of the respective availabilities of these two food sources, remain unclear

The simplest approach to determining trophic linkages between a consumer and its prey is the direct observation of feeding behavior (Majdi et al. 2018). However, such observations are particularly difficult in the fine sediment of the benthic environment, due to the high turbidity of the overlying water, enhanced by from the suspension of sediment due to the movements of foraging consumers (Kneib 1985). As an alternative approach, a visual analysis can be performed on the gut contents of consumers, but such studies are subject to biases due to differences in digestion rates between food items (Alheit \& Scheibel 1982, Scholz et al. 1991). The overall impact of predation on the meiofauna can be evaluated by excluding predators over small (Hall et al. 1990) or large scales (Carpenter et al. 1995, Deegan et al. 2007). However, the effects of predation are confounded with indirect effects, such as depletion of the meiofaunal food source (Ólafsson et al. 1993) and/or physical disturbance due to regular bioturbation by predators (Austen \& Widdicombe 1998, Schratzberger \& Warwick 1999, Ólafsson 2003, Fleeger et al. 2008). The use of stable isotopes is considered to be a powerful tool for determining nutrient sources for consumers, as stable carbon and nitrogen ratios are largely determined by diet (Fry 2006). The full potential of stable isotopes is closely linked to the discrimination of potential food sources in terms of isotopic composition. Stable isotopes can also be used as tracers, after the artificial enrichment of preys. This approach has been used to evaluate the ingestion of bacteria and microphytobenthos by meiofauna (Moodley et al. 2002, Pascal et al. 2008b, Pascal et al. 2008c), macrofauna (Pascal et al. 2008a, Leroy et al. 2012) and fishes (Como et al. 2018). A similar approach has also been used to measure the consumption of macroalgae (Pascal \& Fleeger 2013, Legrand et al. 2018). However, to our knowledge, this approach has never been used to assess the ingestion of meiofauna and macrofauna by predators. 

Improvements in our understanding of the complexity of benthic marine food webs

91 require both $i$ ) improvements in the quantification of the fraction of the meiofauna transferred 92 to higher trophic levels and ii) evaluations of potential variations of this trophic flux 93 according to the availability of other food sources. The aim of this study was to measure the 94 simultaneous ingestion of meiofauna and macrofauna by common dwellers of the tropical 95 intertidal mudflat of the coast of Amazonia. 
This study was performed in the intertidal mudflat of Awala-Yalimapo $\left(05^{\circ} 44^{\prime} 44^{\prime \prime} \mathrm{N}\right.$, $\left.53^{\circ} 55^{\prime} 36^{\prime} \mathrm{W}\right)$, in Western French Guiana, $850 \mathrm{~km}$ away from the mouth of the Amazon River

(Fig 1). The study site has a humid tropical climate, with a wet season from January to July and a dry season from August to the end of December. This coast is subject to a semidiurnal tidal cycle, with a tidal range of $0.8 \mathrm{~m}$ (neap tides) to $2.9 \mathrm{~m}$ (spring tides). Over the course of the year, mud temperature oscillates between 29 and $33^{\circ} \mathrm{C}$, sediment pore water salinity varies between 12 and 46 and sediment organic content fluctuates between 5.6 and 6.8\% (Nguyen et fluid mud adjacent to an area of consolidated mud with young mangrove trees.

In this area, meiofaunal abundance fluctuates between $1.7 \times 10^{6}$ and $4.4 \times 10^{6}$ ind. $\mathrm{m}^{-2}$, equivalent to dry weights of 3.3 and $8.3 \mathrm{~g} \mathrm{~m}^{-2}$, respectively, and the community is dominated by nematodes, with harpacticoid copepods and other groups (Ostracods, Platyhelminthes and Molluscs) accounting for only $26 \%$ and less than $1 \%$, respectively, of the benthic meiofauna (Dupuy et al. 2015). The term "macrofauna" is used here for animals with a length of $0.5 \mathrm{~mm}$ to $20.0 \mathrm{~mm}$. The macrofauna is not very diverse and is dominated by a small number of few taxa, such as tanaids, with the species Halmyrapseudes spaansi accounting for $84 \%$ of macrofauna specimens, with mean abundances from 2,600 ind. $\mathrm{m}^{-2}$ to up to 73,000 ind. $\mathrm{m}^{-2}$ corresponding to a maximum dry weight of $12.1 \mathrm{~g} \mathrm{~m}^{-2}$ (Jourde et al. 2017; Nguyen et al. 2018). The macrofauna also includes members of the Polychaetes and, to a lesser extent,

119 Gastropods and Nemertea (Jourde et al. 2017). The macrofaunal community is dominated by 120 small species, such as $H$. spaansi, which never exceeds $6.4 \mathrm{~mm}$ in length (Nguyen et al. 121 2018). In this study, organisms of more than $20 \mathrm{~mm}$ in length, with the potential to ingest meiofauna and macrofauna, are considered to be predators. We focused on the most common 
123 predators at this site, collected locally: the crab C. bocourti, the shrimp F. subtilis and the 124 highfin goby G. oceanicus. The abundances of $C$. bocourti and $F$. subtilis have never been 125 evaluated in the study area. The abundance of the high fin goby G. oceanicus was previously 126 estimated from benthic cores, which showed this species to have a patchy distribution, with 127 densities of up to 50 ind. $\mathrm{m}^{-2}$ (Jourde et al. 2017). All feeding experiments were performed 128 during the dry season, in November 2015.

Predator sampling

The uppermost centimeter of the sediment was collected from the mudflat at low tide,

131 with a large rectangular scoop. The sediment was sieved with $63 \mu \mathrm{m}$ and $500 \mu \mathrm{m}$ meshes, to extract the meiofauna and macrofauna, respectively. C. bocourti and F. subtilis were collected at high tide, with a $500 \mu \mathrm{m}$-mesh landing net, G. oceanicus specimens were collected by hand, from their burrows, at low tide.

The study site has two advantages for studies of this type: i) easy extraction of the meiofauna and macrofauna by sieving, because the sediment consists primarily of particles of less than $63 \mu \mathrm{m}$ in diameter (Dupuy et al. 2015) and ii) ease of experimental manipulation of the macrofaunal community, due to its low diversity, dominated by a species of small tanaids (Jourde et al. 2017, Nguyen et al. 2018). Sediment was sampled as previously described. For the accurate control of prey availability, sediment depleted of as many meiofauna and macrofauna as possible was required. The sediment was therefore sieved, and the fraction passing through a $63 \mu \mathrm{m}$ mesh was allowed to settle overnight, after which the overlying water was removed (Fig. 2). A $1 \mathrm{~cm}$ layer of this deposited sediment and 1 liter of local seawater, filtered through a $50 \mu \mathrm{m}$-mesh sieve, were placed in each $200 \mathrm{~cm}^{2}$ aquarium used 146 for feeding experiments ( $n=16$ and control $(n=1)$; Table 1). Enriched ${ }^{13} \mathrm{C}$ glucose and ${ }^{15} \mathrm{~N}$ 147 ammonium were added separately to the sediment to label the bacteria and/or 148 microphytobenthos for the secondary labeling of their grazers: the meiofauna and 
macrofauna. For the preparation of labeled meiofauna, the sediment was sieved and the

150 fraction passing through a $500 \mu \mathrm{m}$ mesh was allowed to settle overnight. This fraction of 151 deposited sediment was mixed with ${ }^{15} \mathrm{NH}_{4} \mathrm{Cl}\left(99 \%{ }^{15} \mathrm{~N}\right.$-enriched $\mathrm{NH}_{4} \mathrm{Cl}$; Euriso-top $)$ at a final 152 concentration of $4 \mathrm{~g} \mathrm{~m}^{-2}$ and incubated. For the preparation of labeled macrofauna, the 153 collected sediment was mixed directly with ${ }^{13} \mathrm{C}$-glucose $\left(99 \%{ }^{15} \mathrm{~N}\right.$-enriched glucose; Euriso154 top) at a final concentration of $2.5 \mathrm{~g} \mathrm{~m}^{-2}$ and incubated. Each type of sediment was $i$ ) placed in 155 a separate large plate, at a thickness of $0.5 \mathrm{~cm}$, ii) incubated under local conditions of 156 temperature $\left(29-33^{\circ} \mathrm{C}\right.$ (Nguyen 2018)) and irradiance (2000 $\mathrm{kW} \mathrm{m}^{-2} \mathrm{y}^{-1}$ (Elana 2017)), and iii) 157 regularly sprayed with freshwater to compensate for evaporation. After four days of 158 incubation, each type of sediment was independently sieved through separate meshes to 159 collect ${ }^{15} \mathrm{~N}$-enriched meiofauna $(63 \mu \mathrm{m})$ and ${ }^{13} \mathrm{C}$-enriched macrofauna $(500 \mu \mathrm{m})$. Each of the 16016 aquaria $\left(200 \mathrm{~cm}^{2}\right)$ used for feeding experiments was filled with $1 \mathrm{~L}$ of seawater and a $1 \mathrm{~cm}$ 161 layer of fauna-free sediment, mixed with variable amounts of enriched meiofauna $\left({ }^{15} \mathrm{~N}\right)$ 162 and/or macrofauna $\left({ }^{13} \mathrm{C}\right)$ and one type of target predator. Species community compositions of 163 enriched preys (meiofauna and macrofauna) were similar in all experiments. First, we 164 increased the abundance of one resource (meiofauna or macrofauna), whilst making the other 165 resource unavailable. Secondly both preys were available simultaneously, in different 166 proportions (table 1). One gram (dry weight) of prey corresponds to $4.6 \times 10^{6}$ meiofauna 167 specimens and $6.1 \times 10^{3}$ macrofauna specimens.

170 hours in a large tank containing oxygenated local seawater and sediment with associated 171 fauna before feeding experiments, to prevent starvation. We released 6 C. bocourti, $15 F$. 172 subtilis or 15 G. oceanicus specimens into each of the experimental aquaria. In the control 173 aquarium, containing the highest abundance of each enriched prey, 15 specimens of $G$. 174 oceanicus were placed in a cage closed with a $63 \mu \mathrm{m}$ mesh, to obtain control predators unable 
to ingest enriched preys. All incubations with predators were performed in oxygenated aquaria, for 2 hours, under local temperature and irradiance conditions. At the end of the incubation period, the predators were collected in an aquarium fish net and immediately frozen $\left(-18^{\circ} \mathrm{C}\right)$.

\section{Isotope analyses and calculations}

For the meiofauna, each stable isotope sample consisted of 700 nematodes or 300 copepods picked at random, by hand, under a dissecting microscope, after extraction from sediment by sieving through a $63 \mu \mathrm{m}$ mesh and Ludox HS40 centrifugation, and pooled (Jonge \& Bouwman 1977). Macrofauna were extracted from sediment by sieving through a $500 \mu \mathrm{m}$ mesh, and six tanaid specimens per sample were pooled. For each set of conditions, three pools of two $C$. bocourti, five $F$. subtilis and five $G$. oceanicus specimens, selected at random, were homogenized in an Ultra-Turrax blender, frozen and freeze-dried.

The nitrogen and carbon isotopic compositions of the various organisms sampled (preys and predators) were determined by EA-IRMS (Isoprime, Micromass, UK). The nitrogen and carbon isotope ratios are expressed in the delta notation $\delta^{15} \mathrm{~N}$ and $\delta^{13} \mathrm{C}$, as follows: $\delta \mathrm{X}=$ $\left[\left(\mathrm{R}_{\text {Reference }} / \mathrm{R}_{\text {Sample }}\right)-1\right] \times 1000$, where $\mathrm{X}=\delta^{15} \mathrm{~N}$ or $\delta^{13} \mathrm{C}$ and $\mathrm{R}$ is the ratio ${ }^{15} \mathrm{~N}:{ }^{14} \mathrm{~N}$ or ${ }^{13} \mathrm{C}:{ }^{12} \mathrm{C}$ in the sample and in the reference material. Results are expressed relative to atmospheric nitrogen for $\mathrm{N}$ and to Vienna Pee Dee Belemnite (VPDB) for C, and are expressed in units of $\%$ \pm standard deviation (SD).

An excess of ${ }^{15} \mathrm{~N}$, above background levels (natural ${ }^{15} \mathrm{~N}$ of predator without enrichment) was considered to constitute ${ }^{15} \mathrm{~N}$ enrichment, and is expressed in terms of specific uptake $(I) . I$ was calculated as the product of excess ${ }^{15} \mathrm{~N}(E)$ and the previously measured $\mathrm{N}$ biomass per predator (Table 2). I was converted into meiofaunal or macrofaunal carbon ingested, with the $\mathrm{C} / \mathrm{N}$ ratio of each prey. $E$ was defined as the difference between the background ( $\left.F_{\text {background }}\right)$ and sample $\left(F_{\text {sample }}\right){ }^{15} \mathrm{~N}$ fractions: $E=F_{\text {sample }}-F_{\text {background, }}$, with $F={ }^{15} \mathrm{~N} /\left({ }^{15} \mathrm{~N}+{ }^{14} \mathrm{~N}\right)=R /(R+$

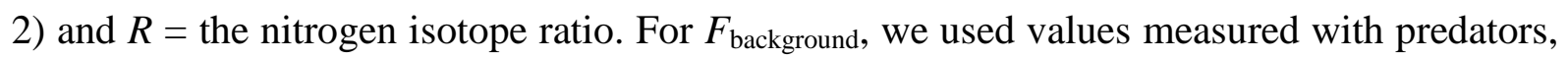


201 without enrichment. $R$ was derived from the measured $\delta^{15} \mathrm{~N}$ values: $\mathrm{R}=\left[\left(\delta^{15} \mathrm{~N} / 1000\right)+1\right] \times$ $202 R$ airN 2 . Prey intake was calculated as $\left[I \times(\mathrm{C} / \mathrm{N}\right.$ ratio of enriched prey $) /\left(F_{\text {enriched prey }} \times\right.$ 203 incubation time)] (Pascal et al., 2008).

204 The incorporation of ${ }^{13} \mathrm{C}$ was calculated in a similar manner, with $F={ }^{13} \mathrm{C} /\left({ }^{13} \mathrm{C}+{ }^{12} \mathrm{C}\right)=$ $205 R /(R+1), R$ airN 2 replaced by $R_{\mathrm{VPDB}}=0.0112372$ and Uptake $=\mathrm{I} /\left(F_{\text {enriched predator }} \times\right.$ incubation 206 time)

\section{Data analyses}

208 One-way analysis of variance (ANOVA) with Tukey post hoc tests was used to analyze 209 the differences between ingestion rates. The normality of the data was first checked in a 210 Shapiro-Wilk test, and homoscedasticity was checked with a Bartlett test. The nonparametric

211 Kruskal-Wallis test was used to assess the differences in isotopic composition $\left(\delta^{15} \mathrm{~N}\right.$ and $\left.\delta^{13} \mathrm{C}\right)$ 212 of preys and predators. The selectivity of prey ingestion was evaluated by fitting a linear 213 model to the data for the ratio of the biomasses of macrofauna to meiofauna ingested, with a $21495 \%$ confidence interval. All statistical analyses were performed with R. Values are presented 215 as means \pm standard deviation (SD) unless otherwise specified. 


\section{$\underline{\text { Results }}$}

The individual dry weight, carbon and nitrogen contents of each type of prey and predator are presented in table 2. Tanaids had a mean individual dry weight 750 times higher than that of nematodes and 300 times higher than that of copepods. The natural isotopic compositions of preys and predators are presented in figure 3. Before enrichment, $\delta^{15} \mathrm{~N}$ and $\delta^{13} \mathrm{C}$ levels were similar in the meiofauna and macrofauna (Tanaidacea) (Kruskall-Wallis, $p>$ 0.05). After enrichment, the $\delta^{15} \mathrm{~N}$ levels of the nematodes and copepods used during feeding experiments were not significantly different (Kruskall-Wallis, $p>0.05$ ), with respective enrichment values ( $\delta$ after enrichment minus $\delta$ at T0) of $261.0 \pm 44.5 \%$ o $(n=6$ samples of 700 specimens $)$ and $268.0 \pm 24.9 \%$ ( $n=6$ samples of 300 specimens $)$. Tanaids had a mean $\delta^{13} \mathrm{C}$ content of $2789.5 \pm 65.6 \%$ ( $n=3$ samples of 6 specimens each $)$. and G. oceanicus (Tab. 2). C. bocourti had a mean width of $1.3 \mathrm{~cm} \pm 0.4(n=42)$ whereas $F$. subtilis and G. oceanicus were $4.4 \mathrm{~cm} \pm 0.9(n=210)$ and $5.0 \mathrm{~cm} \pm 2.0(n=180)$ long, respectively. The natural isotopic compositions of all predators (Fig. 3) were similar for $\delta^{13} \mathrm{C}$ 233 (Kruskall-Wallis, $p>0.05$ ), whereas $F$. subtilis and G. oceanicus had significantly different $\delta^{15} \mathrm{~N}$ levels (Kruskall-Wallis, $\left.p<0.01\right)$.

G. oceanicus caged in the aquarium with the highest abundances of each of the enriched preys had significantly higher ${ }^{13} \mathrm{C}$ and ${ }^{15} \mathrm{~N}$ levels than the natural isotopic composition samples (Kruskall-Wallis, $p<0.05)$, by $1.5 \pm 0.5$ and $2.1 \pm 0.7 \%$, respectively $(n=3)$. These enrichment levels correspond to $2.7 \%$ for ${ }^{13} \mathrm{C}$ and $7.1 \%$ for ${ }^{15} \mathrm{~N}$ relative to free specimens of G. oceanicus able to ingest enriched preys in similar incubation conditions.

Meiofauna ingestion by $C$. bocourti was not significantly affected by meiofauna 241 abundance, and the values obtained ranged from 11.8 to $18.9 \mathrm{mgC}_{\text {prey }} \mathrm{gC}_{\text {predator }}{ }^{-1} \mathrm{~h}^{-1}$, which is 
242 equivalent to 3584 to 5766 nematode ind $^{-1} \mathrm{~h}^{-1}$ (Fig. 4). By contrast, the ingestion of 243 meiofauna by $F$. subtilis and $G$. oceanicus increased with meiofauna abundance and was 244 significantly higher at the highest meiofauna abundance tested (Fig. 4), at reaching $12.7 \pm 1.0$ $245 \mathrm{mgC}_{\text {prey }} \mathrm{gC}_{\text {predator }}{ }^{-1} \mathrm{~h}^{-1}\left(6342 \pm 516\right.$ nematode ind $\left.^{-1} \mathrm{~h}^{-1}\right)$ and $4.6 \pm 0.5 \mathrm{mgC}_{\text {prey }} \mathrm{gC}_{\text {predator }}{ }^{-1} \mathrm{~h}^{-1}$ $246 \quad\left(3120 \pm 363\right.$ nematodes ind $\left.^{-1} \mathrm{~h}^{-1}\right)$, respectively.

247 The ingestion of macrofauna by $C$. bocourti was not significantly affected by prey 248 abundance and ranged from 1.2 to $4.5 \mathrm{mgC}_{\text {prey }} \mathrm{gC}_{\text {predator }}{ }^{-1} \mathrm{~h}^{-1}$, equivalent to 2.0 to 2.9 tanaid 249 ind $^{-1} \mathrm{~h}^{-1}$ (Fig. 5). By contrast, the ingestion of macrofauna by $F$. subtilis and G. oceanicus 250 increased significantly with macrofauna abundance, reaching $5.6 \pm 0.2 \mathrm{mgC}_{\text {prey }} \mathrm{gC}_{\text {predator }}{ }^{-1} \mathrm{~h}^{-1}$

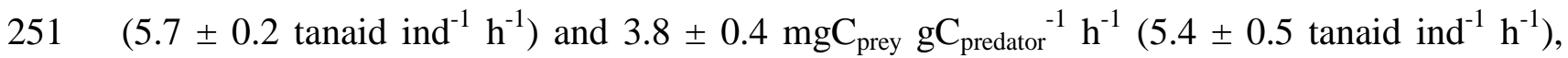
252 respectively (Fig. 5).

253 The ability of predators to ingest their food in a selective manner was evaluated by 254 calculating the differences between the ratios of macrofauna to meiofauna ingested and ratios 255 of macrofauna to meiofauna available in the environment (Fig. 6). If these two ratios were 256 similar, it was concluded that there was no selection, whereas differences between these ratios 257 were interpreted as indicating the preferential ingestion of meiofauna or macrofauna. For each 258 predator, we fitted a linear model with a 95\% confidence interval to the data (Fig. 6). For $C$. 259 bocourti, this confidence interval included all theoretical values for non-selective ingestion, 260 reflecting an absence of selection in feeding behavior. For F. subtilis and G. oceanicus, the 261 lowest values of the $95 \%$ confidence interval were always higher than the theoretical values, 262 implying a preferential ingestion of macrofauna over meiofauna by both these predator 263 species. 


\section{$\underline{\text { Discussion }}$}

The aim of this study is improve our understanding of benthic marine food webs by

268 the quantification of ingestion of meiofauna and macrofauna by higher trophic levels in a tropical intertidal mudflat on the coast of Amazonia

\section{Meiofauna predation}

The effect of top-down control on the meiofauna is unclear. Several studies have suggested that predation on the meiofauna is negligible due to the ability of the meiofauna to disperse (Giere 2009) and fast turnover times, whereas predators are comparatively rare (Gibbons 1988, Shaw \& Jenkins 1992, Coull 1999). On the contrary, other studies have concluded that predation affects meiofauna abundance (Danovaro et al. 2007, Fleeger et al. 2008) and community composition ( $\mathrm{Li}$ et al. 1996, O'Gorman et al. 2008). These discrepancies may reflect biases associated with the different methods used to evaluate trophic fluxes (see below in the part Methodological considerations). Differences in the conclusions drawn may also reflect differences in trophic links between study sites.

Estimations of the top-down effect of predators require knowledge of their abundance.

In the study area, the abundances of $C$. bocourti and $F$. subtilis have unfortunately never been evaluated. However, abundances of the high fin goby G. oceanicus have been estimated from measurements in benthic cores, revealing a patchy distribution, with densities reaching 50 ind. $\mathrm{m}^{-2}$ (Jourde et al. 2017). For evaluation of the maximum top-down effect, daily ingestion was calculated, taking into account the highest abundance of fish and lowest abundance of meiofauna (Dupuy et al. 2015), and the highest ingestion rate measured in this study. This area of the mudflat is submerged and exposed to fish predation for only six hours per day (24 h). This maximum daily ingestion would therefore reach $56 \%$ of the standing stock of 
grazers, such as shrimps and crabs, were not considered, as their natural abundances remain

291 unknown and $\mathrm{ii}$ ) gobies have a patchy distribution and are not realistically sampled by benthic

292 cores. However, our results nevertheless suggest that the meiofauna community could be 293 regulated by predation, at least during the limited periods during which predators are 294 abundant as previously suggested by other studies (Danovaro et al. 2007, Fleeger et al. 2008).

\section{Meiofauna predators}

Body size is an important determinant of many physiological processes, and maximal ingestion rate is generally inversely correlated with body size (Peters, 1983). This assumption was confirmed in this study, as maximum rates of meiofauna ingestion decreased with increasing predator weight, from crab to fish. In shrimp, the maximum daily meiofauna ingestion rate corresponded to $30 \%$ of the predator's body weight. This rate is higher than that 301 estimated for the shrimp Crangon crangon, which eats 8-16\% (del Norte-Campos \& 302 Temming 1994, Feller 2006) or 10-12\% (Pihl \& Rosenberg 1984) of its own body weight daily. This higher level of ingestion activity may be due to different evaluation techniques or to the higher temperature in the tropical environment of $F$. subtilis than in the habitat of $C$. crangon.

Theoretically, food uptake by a consumer should increase with food abundance.

307 However, beyond a certain threshold prey density, uptake rates remain constant, according to 308 Holling's prey-dependent type II functional response (Holling 1959), as reported for shrimp 309 (Gregg \& Fleeger 1998). The threshold value was not reached here for F. subtilis and G. 310 oceanicus. As the natural abundance of the meiofauna (Dupuy et al. 2015) and macrofauna 311 (Nguyen et al. 2018) can exceed the abundances tested here, ingestion rates could be higher 312 than the measured values, for both preys. The meiofauna constitutes a potentially high-quality food source, due to the high 314 levels of unsaturated fatty acids in these animals (Fleeger 2007, Leduc et al. 2009, De Troch 315 et al. 2012, Braeckman et al. 2015). The meiofauna is strongly associated with sediment 
particles. When consuming the meiofauna, predators can i) ingest bulk sediment, which

317 entails a high cost in terms of the rejection of non-digestible material or $i i$ ) selectively ingest

318 the meiofauna, which entails a high cost in food selection. In this study, the three predators

319 have different feeding mechanisms for selecting their food. Juvenile crabs of the genus

320 Callinectes selectively ingest microbes rather than bulk detritus (Fantle et al. 1999). Penaid

321 shrimps feed selectively, with their chelate pereiopods grasping and transporting acceptable

322 morsels of food to the mouth (Hindley \& Alexander 1978). Gobies graze more or less

323 indiscriminately on sediment, in addition to predating on larger preys on sight (Fitzhugh \&

324 Fleeger 1985, Hamerlynck \& Cattrijsse 1994). The predators studied have different weight

325 ranges, with the crab $C$. bocourti smaller than the goby G. oceanicus by a factor of 1.6.

326 According to optimal foraging theory, that the greatest rewards per unit effort are obtained by

327 predating on the largest graspable prey items (Krebs 1978). Development shifts in diet, from

328 smaller meiofauna to larger macrofauna, have been reported for the crab Carcinus maenas

329 (Reise 1978, Scherer \& Reise 1981). The shrimp Crangon crangon displays a similar dietary

330 shift when its total body length exceeds $20 \mathrm{~mm}$ (Pihl \& Rosenberg 1984, Gee 1987).

331 Similarly, in our study, the shrimp F. subtilis, with a mean length of $44 \mathrm{~mm}$, also

332 preferentially ingested macrofauna. For fish, the switch from meiofauna to macrofauna

333 appears to occur at a threshold total length of 3-4 cm (Gee 1989), as previously reported for

334 several goby species from the Adriatic Sea (Kovačić \& la Mesa 2008), Baltic Sea (Aarnio \&

335 Bonsdorff 1993), North Sea (Schückel et al. 2013) and Atlantic Ocean (D'Aguillo et al. 2014).

336 The results reported here are consistent with this assumption, as gobies of $5 \mathrm{~cm}$ or more in

337 length preferentially ingested macrofauna.

338 The experiments reported here suggest an important role of the macrofauna and 339 meiofauna in the diet of $G$. oceanicus, but natural isotopic composition revealed limited $\delta^{15} \mathrm{~N}$ 340 enrichment between the preys and the goby, suggesting that other food items not considered 341 here, such as detritus or microphytobenthos, might play a role in the diet of these fish. Despite 
preferential macrofauna ingestion, large G. oceanicus specimens continued to ingest

343 meiofauna, unlike other goby species of similar size (de Morais \& Bodiou 1984). Gobies can

344 be opportunist predators with a diet reflecting variations in the food available (D'Aguillo et al.

345 2014). In the Awala mudflat, the abundance of tanaids varies by a factor of $10^{3}$, depending on

346 the season (Nguyen et al. 2018). The meiofauna may, therefore, play an important role in the

347 diet of the predator in conditions of lower macrofauna availability. Such seasonal variations in

348 the trophic role of the meiofauna have already been suggested for fish (Schückel et al. 2013).

349 Gobies switch to the ingestion of smaller items when in competition for food resources or if 350 the availability of large preys decreases (Henry \& Jenkins 1995). Fluxes from the meiofauna 351 to higher trophic levels appeared complexes and likely variable along the year suggesting that 352 a temporal survey would be useful to clarify the trophic role of meiofauna. Despite those 353 potential variations, the present study provides quantitative fluxes embeddable in ecological 354 models of benthic food webs.

\section{Methodological considerations}

The potential of stable isotopes for studies of this kind depends heavily on the difference in isotopic composition between the food sources to be distinguished. In this study, the meiofaunal community and tanaids had similar isotopic compositions, rendering interpretation of the patterns obtained with natural isotopes difficult and necessitating the use of enrichment experiments.

Predator abundance in the study area had been determined only for G. oceanicus

362 (Jourde et al. 2017). For the purpose of feeding, the predators studied perform tidal 363 migrations, following the rising tide by swimming or walking over the sediment on the 364 bottom (Gibson, 2003). They can reach very high densities during this migration, and the 365 shrimp (F. subtilis) and crab (C. bocourti) species studied were chosen on the basis of their high abundance and availability at the time of the experiments. Incubations were performed 
with high abundances of predators, potentially affecting predator interactions and feeding behavior, resulting in a possible underestimation of ingestion rates.

Copepods have a caloric value $35 \%$ higher than those of most members of the meiofauna (Gee 1989). Copepods generally dwell closer to the sediment surface than nematodes, and display emergence behavior relative to the water column (Giere 2009). This differential distribution would facilitate predation on copepods by shrimps (Pihl \& Rosenberg 1984, Gee 1987) and fishes (Coull 1990, McCall \& Fleeger 1995). However, it was not possible to differentiate between copepods and nematodes in this study, because these two groups were labeled similarly. The availability of sediment in the aquarium constituted realistic incubation conditions, because the sediment serves as a refuge, reducing the risk of predation for meiofauna and macrofauna (Arnold 1984, Lipcius \& Hines 1986, Gregg \& Fleeger 1998). Feeding experiments were run over a short period of two hours and did not, therefore, necessarily yield results representative of feeding behavior over longer time scales, as the feeding activity of the predators studied is known to fluctuate over the day (Hagerman \& Østrup 1980, Ryer 1987, Kanou et al. 2005). However, short incubation times were used here, to limit $i$ ) label exchange between meiofaunal and macrofaunal preys and $i i$ ) the excretion of ingested label by predators. This excretion bias would be limited, as feeding experiments lasted two hours and gut retention time would not exceed this duration for Portunidae crabs (Serrano 2012) or Gobiidae fish (Kanou et al. 2005). However, this bias could be larger for Penaidae shrimps, which have gut retention times of between one and four hours (Hoyt et al. 2000).

The isotopic compositions of predators changed slightly following their transfer to a mesh cage in an aquarium containing enriched preys. This finding suggests that any bias due to the inefficient removal of unincorporated label by rinsing would be limited, and that the enrichments observed with free predators were due principally to trophic processes. The mud sediment of French Guiana is dominated by silt (70-85\%) and clay (10-15\%), and mean 
393 particle size is below $63 \mu \mathrm{m}$ (Dupuy et al. 2015). The fauna thus represents a large portion of 394 the material remaining on the $63 \mu \mathrm{m}$ mesh after sieving. However, a small fraction of detritus 395 would also have been present and the associated bacteria would have taken up glucose- ${ }^{13} \mathrm{C}$ or 396 ammonium- ${ }^{15} \mathrm{~N}$ during the enrichment process. The ingestion of this enriched detritus by 397 predators would then lead to an overestimation of the ingestion of meiofauna and macrofauna. 398 This bias should be borne in mind when interpreting the results. Despite this shortcoming, the 399 method used here has several advantages: $i$ ) the measurement of ingestion fluxes, $i i$ ) dual 400 labeling of preys, making it possible to evaluate feeding preferences and, iii) ease of use, with 401 incubations possible even at remote sites with limited technical resources.

\section{Conclusion}

The use of stable isotope-enriched meiofauna and macrofauna in feeding experiments 404 is an appropriate method for evaluating preferential ingestion. In these experiments, feeding rates increasing with the availability of meiofauna and macrofauna food for all predators other 406 than the crabs, suggesting that rates of ingestion of both preys may actually be higher than 407 measured. All three predators studied ingested meiofauna, but the contribution of the 408 meiofauna to the diet decreased with increasing predator size (C. bocourti $>$ F. subtilis $>$ G. 409 oceanicus), whereas no such relationship to size was observed for the macrofauna. Larger 410 predators preferentially ingested macrofauna to a greater extent than smaller predators, in 411 accordance with optimal foraging theory. For larger predators, the meiofauna is an important 412 component of the diet only at early stages of development or in the absence of large food 413 items. 
$416 \quad$ Figure and table

417 Table 1. Measured prey abundances (dry weights of meiofauna and macrofauna in $\mathrm{g} \mathrm{m}^{-2}$ ) in 418 dual-prey feeding experiments in 16 independent aquariums. Each letter refers to a predator.

419 A: C. bocourti $(n=4)$, B: F. subtilis $(n=6)$ and C: G. oceanicus $(n=6)$

\begin{tabular}{|c|c|c|c|c|}
\hline & \multicolumn{3}{|c|}{ Meiofauna $\left(\mathrm{g} \mathrm{m}^{-2}\right)$} \\
\hline & & 3.7 & 9.1 & 22 \\
\hline \multirow{5}{*}{ Macrofauna $\left(\mathrm{g} \mathrm{m}^{-2}\right)$} & 0.9 & & $\mathrm{~A}, \mathrm{~B}, \mathrm{C}$ & \multirow{5}{*}{ C } \\
\hline & 1.3 & A, B & $\mathrm{A}, \mathrm{B}$ & \\
\hline & 1.8 & $\mathrm{C}$ & $\mathrm{B}, \mathrm{C}$ & \\
\hline & 3.7 & & $\mathrm{~A}, \mathrm{~B}, \mathrm{C}$ & \\
\hline & 7.3 & & $\mathrm{~B}, \mathrm{C}$ & \\
\hline
\end{tabular}

420 
423 Table 2. Dry weight, carbon and nitrogen weights per specimen of prey (nematode, copepod,

424 Tanaidacea) or predator (C. bocourti, F. subtilis, G. oceanicus) (mean $\pm \mathrm{SD}, n$ : number of 425 samples and number of specimens per sample used to evaluate these weights).

\begin{tabular}{lccccc} 
& $\begin{array}{c}\text { Individual dry } \\
\text { weight }\end{array}$ & $\begin{array}{c}\text { Individual carbon } \\
\text { weight }\end{array}$ & $\begin{array}{c}\text { Individual nitrogen } \\
\text { weight }\end{array}$ & n & $\begin{array}{c}\text { Specimens } \\
\text { per sample }\end{array}$ \\
\hline Nematoda & $217 \pm 61 \mathrm{ng}$ & $94 \pm 29 \mathrm{ng}$ & $23 \pm 8 \mathrm{ng}$ & 6 & 700 \\
Copepoda & $534 \pm 92 \mathrm{ng}$ & $209 \pm 31 \mathrm{ng}$ & $47 \pm 7 \mathrm{ng}$ & 6 & 300 \\
Tanaidacea & $162 \pm 45 \mu \mathrm{g}$ & $46 \pm 11 \mu \mathrm{g}$ & $10 \pm 2 \mu \mathrm{g}$ & 6 & 6 \\
C. bocourti & $95 \pm 36 \mathrm{mg}$ & $29 \pm 13 \mathrm{mg}$ & $6 \pm 3 \mathrm{mg}$ & 45 & 2 \\
F. subtilis & $122 \pm 41 \mathrm{mg}$ & $47 \pm 18 \mathrm{mg}$ & $13 \pm 5 \mathrm{mg}$ & 57 & 5 \\
G. oceanicus & $156 \pm 92 \mathrm{mg}$ & $65 \pm 41 \mathrm{mg}$ & $18 \pm 11 \mathrm{mg}$ & 54 & 5
\end{tabular}




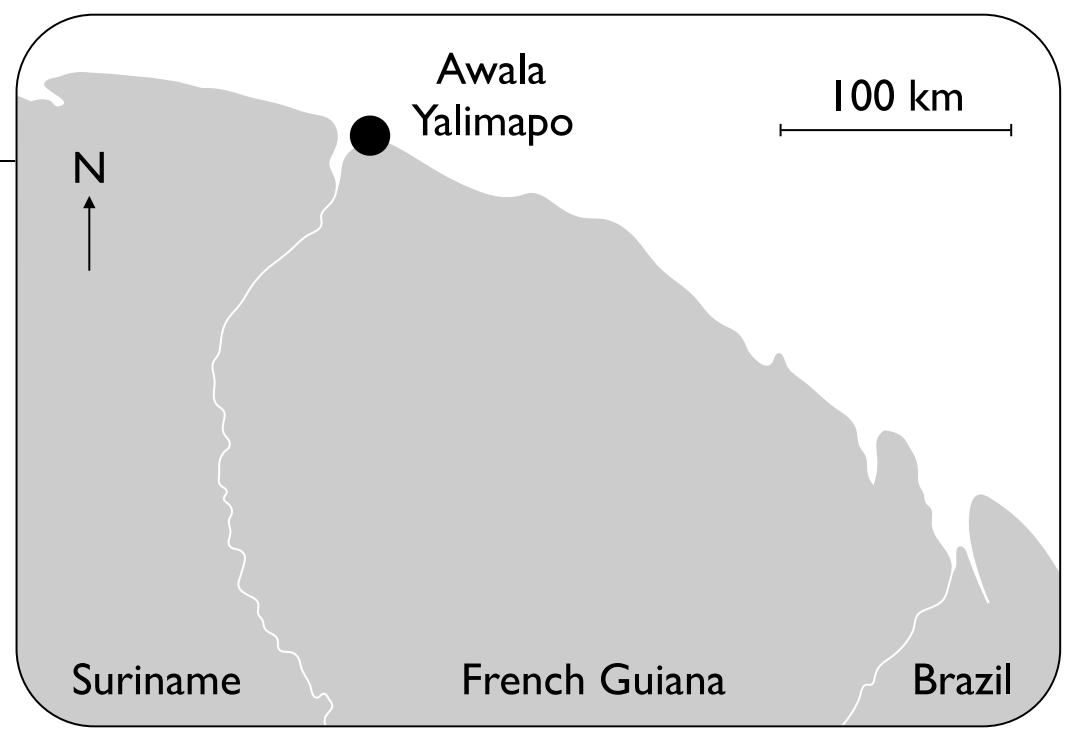

431 Figure 1. Location of the Awala-Yalimapo study site in French Guiana 


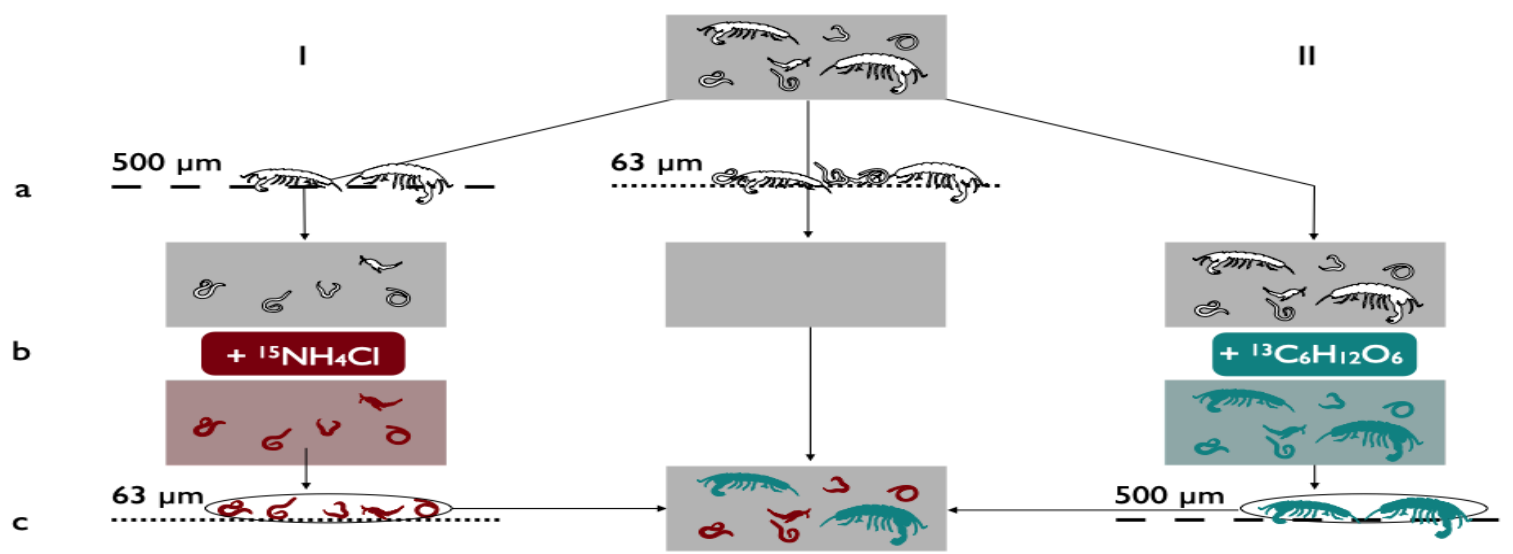

Figure 2

436 Figure 2. Diagram of the protocol for enrichment of the meiofauna (I) and macrofauna (II):

437 the sediment was a) passed through a $500 \mu \mathrm{m}$ mesh for I and left untreated for II, b) mixed 438 with ${ }^{15} \mathrm{NH}_{4} \mathrm{Cl}$ for I and ${ }^{13} \mathrm{C}$-glucose for II and incubated for four days, c) passed through 439 meshes of $63 \mu \mathrm{m}$ for I and $500 \mu \mathrm{m}$ for II, to collect the ${ }^{15} \mathrm{~N}$-enriched meiofauna and ${ }^{13} \mathrm{C}$ 440 enriched macrofauna, respectively. The enriched fauna was mixed with non-enriched 441 sediment devoid of fauna obtained with a $63 \mu \mathrm{m}$-mesh sieve 


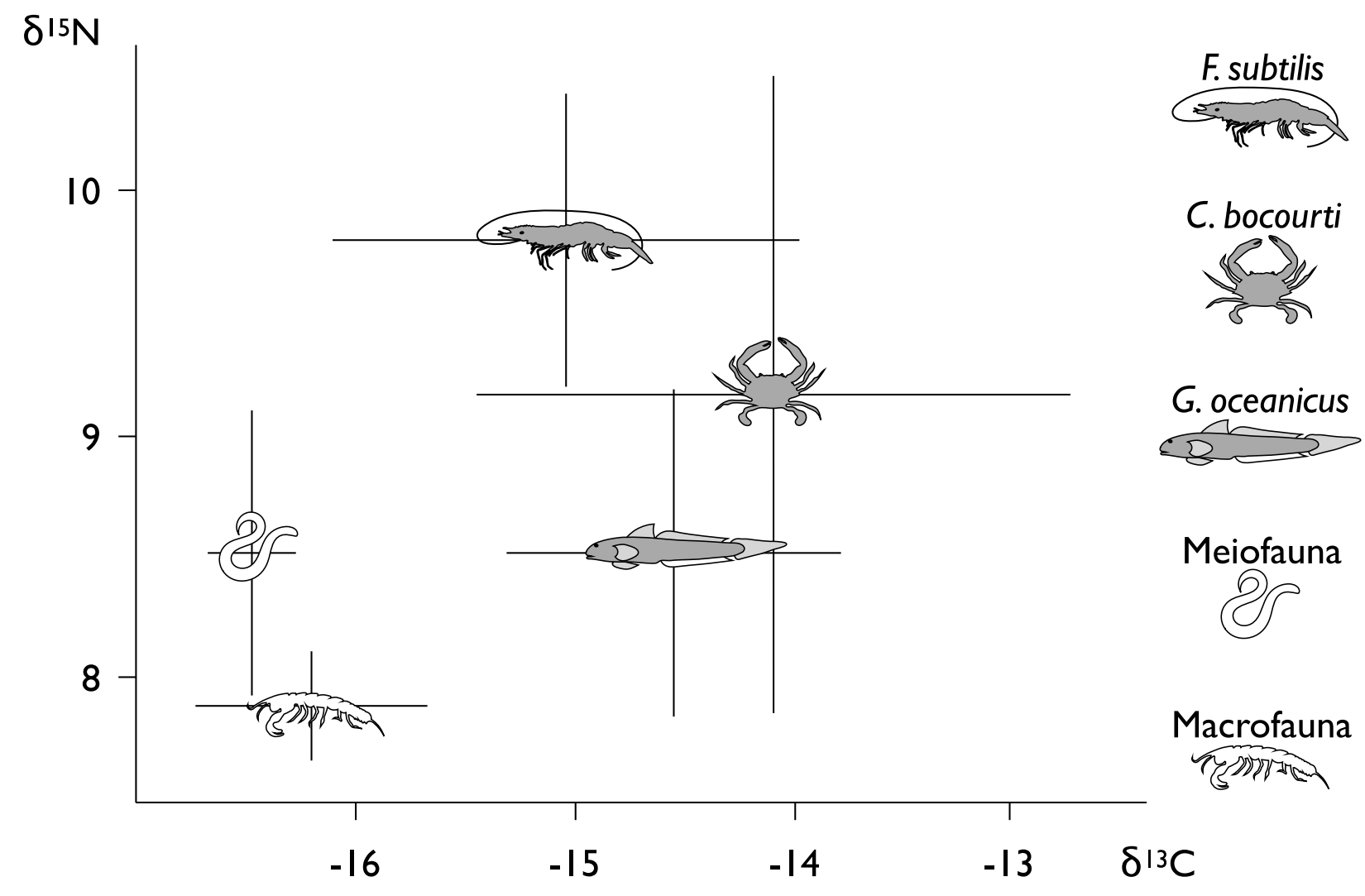

446 Figure 3. Natural isotopic composition $\left(\delta^{15} \mathrm{~N}\right.$ as a function of $\left.\delta^{13} \mathrm{C}, \pm \mathrm{SD}, n=6\right)$ of preys 447 (meiofauna and macrofauna) and predators (C. bocourti, F. subtilis and G. oceanicus) 


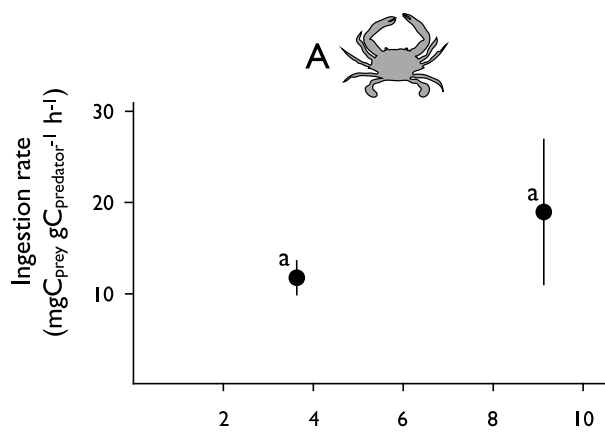

Meiofauna abundance $\left(\mathrm{mg} \mathrm{m}^{-2}\right)$

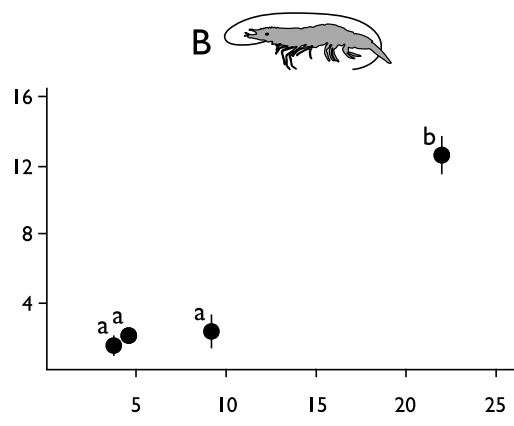

Meiofauna abundance $\left(\mathrm{mg} \mathrm{m}^{-2}\right)$
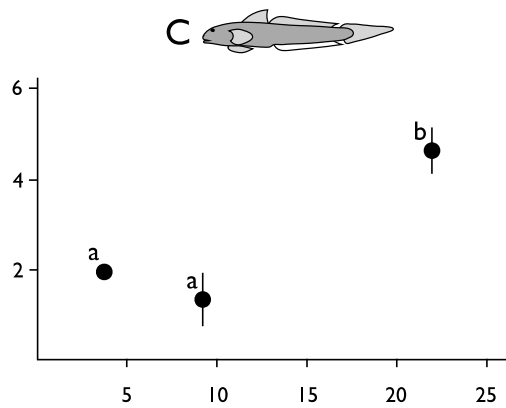

Meiofauna abundance $\left(\mathrm{mg} \mathrm{m}^{-2}\right)$

451 Figure 4. Ingestion of meiofauna $\left(\mathrm{mgC}_{\text {prey }} \mathrm{gC}_{\text {predator }}{ }^{-1} \mathrm{~h}^{-1} ; \pm \mathrm{SD}, n=3\right)$ by $C$. bocourti (A), $F$. 452 subtilis (B) and G. oceanicus (C) as a function of dry meiofauna biomass ( $\left.\mathrm{mg} \mathrm{m}^{-2}\right)$. Different 453 lower-case letters indicate significant differences between the tested abundances (ANOVA, 454 Tukey test, $p<0.005)$ 


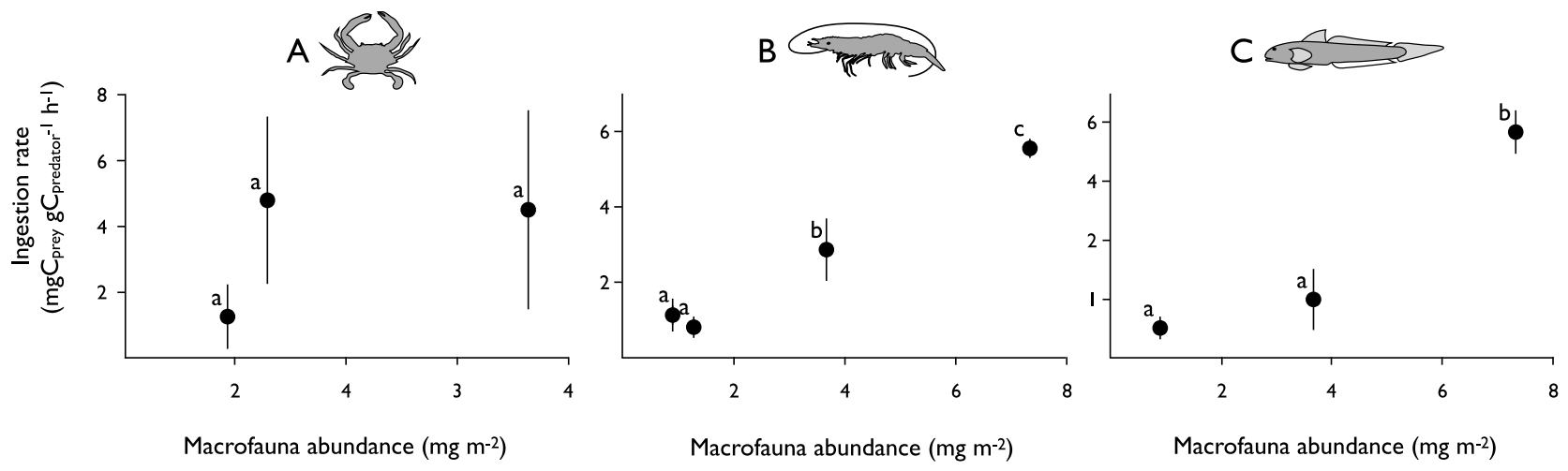

458 Figure 5. Ingestion of macrofauna $\left(\mathrm{mgC}_{\text {prey }} \mathrm{mgC}_{\text {predator }}^{-1} \mathrm{~h}^{-1} ; \pm \mathrm{SD}, n=3\right)$ by C. bocourti (A), 459 F. subtilis (B) and G. oceanicus (C) as a function of dry macrofauna biomass ( $\mathrm{mg} \mathrm{m}^{-2}$ ). 460 Different lower-case letters indicate significant differences between the tested abundances 461 (ANOVA, Tukey test, $p<0.005$ ). 


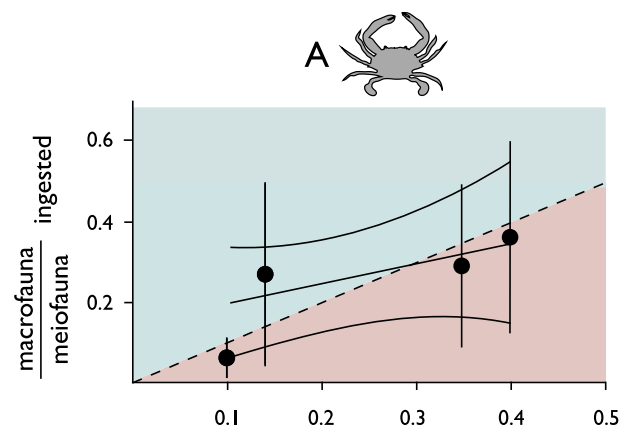

$\frac{\text { macrofauna }}{\text { meiofauna }}$ available

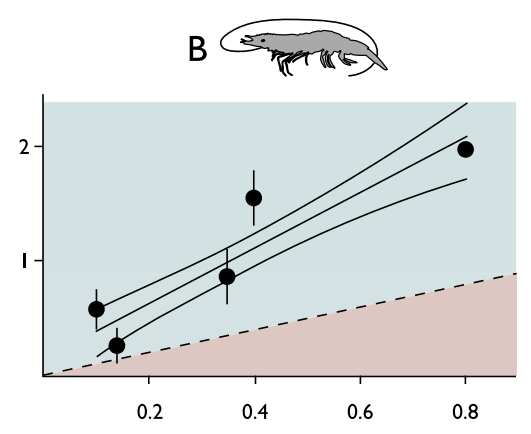

$\frac{\text { macrofauna }}{\text { meiofauna }}$ available
$C \stackrel{3}{3}$

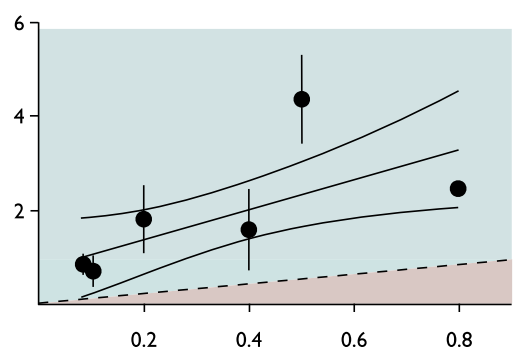

$\frac{\text { macrofauna }}{\text { meiofauna }}$ available

465 Figure 6. Ratio of the biomasses of macrofauna and meiofauna ingested plotted against the

466 ratio of biomasses of macrofauna and meiofauna available ( $\pm \mathrm{SD}, n=3)$ ), for $C$. bocourti (A),

467 F. subtilis (B) and G. oceanicus (C). The dotted line corresponds to a theoretical absence of

468 selection. Points above (blue part) or below (red part) the dotted line indicate the selective

469 ingestion of macrofauna and meiofauna, respectively. The linear models fitted to the data are

470 presented as solid lines with $95 \%$ confidence intervals 


\section{$\underline{\text { Acknowledgements }}$}

We would like to thank Antoine Gardel (CNRS Guiana) for technical support in the

476 field, Céline Artero for her help with field work, Jerome Jourde (University of La Rochelle)

477 for identifying $C$. bocourti and $F$. subtilis and 3 anonymous reviewers for helpful comments.

478 This work received financial support from the CNRS, CNRS Guiana, the University of La 479 Rochelle and the European Fund for Regional Development (FEDER).

480

\section{Compliance with ethical standards}

human participants performed by any of the authors. All applicable international, national 


\section{$\underline{\text { Reference }}$}

Aarnio K, Bonsdorff E (1993) Seasonal variation in abundance and diet of the sand goby Pomatoschistus minutus (Pallas) in a northern Baltic Archipelago. Ophelia 37: 19-30 Alheit J, Scheibel A (1982) Benthic harpacticoids as a food source for fish. Mar Biol 70: 141-147

Aller RC, Aller JY (1992) Meiofauna and solute transport in marine muds. Limnol Oceanogr 37: 1018-1033

Arnold WS (1984) The effects of prey size, predator size, and sediment composition on the rate of predation of the blue crab, Callinectes sapidus Rathbun, on the hard clam, Mercenaria mercenaria (Linné). J Exp Mar Biol Ecol 80: 207-219

Austen MC, Widdicombe S (1998) Experimental evidence of effects of the heart urchin Brissopsis lyriferaon-associated subtidal meiobenthic nematode communities. J Exp Mar Biol Ecol 222: 219-238

Bell SS, Coull BC (1978) Field evidence that shrimp predation regulates meiofauna. Oecologia 35: $141-148$

Bonaglia S, Nascimento FJA, Bartoli M, Klawonn I, Brüchert V (2014) Meiofauna increases bacterial denitrification in marine sediments. Nat Commun 5: 5133

Braeckman U, Provoost P, Sabbe K, Soetaert K, Middelburg JJ, Vincx M, Vanaverbeke J (2015) Temporal dynamics in a shallow coastal benthic food web: insights from fatty acid biomarkers and their stable isotopes. Mar Environ Res 108: 55-68

Carpenter SR, Chisholm SW, Krebs CJ, Schindler DW, Wright RF (1995) Ecosystem experiments. Science 269: 324-327

Como S, Carpentier A, Rossi F, Dupuy C, Richard P, Feunten E, Lefrancois C (2018) Stable isotope as tracers can reveal resource allocation in juvenile golden gray mullets (Liza aurata, Risso, 1810). J Exp Mar Biol Ecol 503: 72-79

Coull BC (1990) Are members of the meiofauna food for higher trophic levels? Trans Am Microsc Soc 109: 233-246

Coull BC (1999) Role of meiofauna in estuarine soft bottom habitats. Aust J Ecol 24: 327-331

D'Aguillo MC, Harold AS, Darden TL (2014) Diet composition and feeding ecology of the naked goby Gobiosoma bosc (Gobiidae) from four western Atlantic estuaries. J Fish Biol 85: $355-$ 373

Danovaro R, Scopa M, Gambi C, Fraschetti S (2007) Trophic importance of subtidal metazoan meiofauna: evidence from in situ exclusion experiments on soft and rocky substrates. Mar Biol 152: 339-350

de Morais T, Bodiou JY (1984) Predation on meiofauna by juvenile fish in a Western Mediterranean flatfish nursery ground. Mar Biol 82: 209-215 
De Troch M, Boeckx P, Cnudde C, Van Gansbeke D, Vanreusel A, Vincx M, Caramujo M-J (2012) Bioconversion of fatty acids at the basis of marine food webs: insight from compoundspecific stable isotope analysis. Mar Ecol Prog Ser 465: 53-67

Deegan LA, Bowen JL, Drake D, Fleeger JW, Fiedrichs CT, Galván KA, Hobbie JE, Hopkinson CS, Johnson DS, Johnson JM, LeMay LE, Miller E, Peterson BJ, Picard C, Sheldom S, Sutherland M, Vallino J, Warren RS (2007) Susceptibility of salt-marshes to nutrient enrichment and predator removal. Ecol Appl 17: S42-S63

del Norte-Campos AGC, Temming A (1994) Daily activity, feeding and rations in gobies and brown shrimp in the northern Wadden Sea. Mar Ecol Prog Ser 115: 41-53

Dupuy C, Nguyen TH, Mizrahi D, Jourde J, Bréret M, Agogué H, Beaugeard L, Bocher P (2015) Structure and functional characteristics of the meiofauna community in highly unstable intertidal mudbanks in Suriname and French Guiana (North Atlantic coast of South America). Cont Shelf Res 110: 39-47

Elana U (2017) Projet de parc solaire de la Sarcelle sur la commune de Mana (Guyane). SUEZ

Fantle MS, Dittel AI, Schwalm SM, Epifanio CE, Fogel ML (1999) A food web analysis of the juvenile blue crab, Callinectes sapidus using stable isotopes in whole animals and individual amino acids. Oecologia 120: 416-426

Feller RJ (2006) Weak meiofaunal trophic linkages in Crangon crangon and Carcinus maenas. J Exp Mar Biol Ecol 330: 274-283

Fitzhugh GR, Fleeger JW (1985) Goby (Pisces: Gobiidae) interactions with meiofauna and small macrofauna. Bull Mar Sci 36: 436-444

Fleeger JW (2007) The potential to mass-culture harpacticoid copepods for use as food far larval fish. In: Lee CS, O'Bryen PJ, Marcus NH (eds) Copepods in Aquaculture. Blackwell Publishing Professional, Ames, Iowa, USA

Fleeger JW, Johnson DS, Galván KA, Deegan LA (2008) Top-down and bottom-up control of infauna varies across the saltmarsh landscape. J Exp Mar Biol Ecol 357: 20-34

Fry B (2006) Stable isotope ecology. Springer, New-York

Gee JM (1987) Impact of epibenthic predators on estuarine intertidal harpacticoid copepod populations. Mar Biol 96: 497-510

Gee JM (1989) An ecological economic review of meiofauna as food for fish. Zool J Limn Soc 96: $243-261$

Gibbons MJ (1988) Impact of predation by juvenile Clinus superciliosus on phytal meiofauna: are fish important as predators? Mar Ecol Prog Ser 45: 13-22

Gibson RN (2003) Go with the flow: tidal migration in marine animals. Hydrobiologia 503: 153161

Giere O (2009) Meiobenthology: the microscopic motile fauna of aquatic sediments. Springer, Berlin

567 Gregg CS, Fleeger JW (1998) Grass shrimp Palaemonetes pugio predation on sediment- and 
stem-dwelling meiofauna: field and laboratory experiments. Mar Ecol Prog Ser 175: 77-86

Hagerman L, Østrup J (1980) Seasonal and diel activity variations in the shrimp Palaemon adspersus from a Brackish, non-tidal area. Mar Ecol Prog Ser 2: 329-335

Hall SJ, Raffaelli D, Turell WR (1990) Predator-caging experiments in marine systems: a reexamination of their value. Am Nat 136: 657-672

Hamerlynck O, Cattrijsse A (1994) The food of Pomatoschistus minutus (Pisces, Gobiidae) in Belgian coastal waters, and a comparison with the food of its potential competitor $P$. lozanoi. J Fish Biol 44: 753-771

Henry BA, Jenkins GP (1995) The impact of predation by the girled goby, Nesogobius sp. 1, on abundances of meiofauna and small macrofauna. J Exp Mar Biol Ecol 191: 223-238

Hindley JPR, Alexander CG (1978) Structure and function of the chelate pereiopods of the banana prawn Penaeus merquiensis. Mar Biol 48: 153-160

Holling CS (1959) Some characteristics of simple types of predation and parasitism. Can Entomol 91: 385-398

Hoyt M, Fleeger JW, Seibeling R, Feller RJ (2000) Serological estimation of prey-protein gutresidence time and quantification of meal size for grass shrimp consuming meiofaunal copepod. J Exp Mar Biol Ecol 248: 105-119

Jonge VND, Bouwman L (1977) A simple density separation technique for quantitative isolation of meiobenthos using the colloidal silica Ludox TM. Mar Biol 42: 143-148

Jourde J, Dupuy C, Nguyen HT, Mizrahi D, da Pracontal N, Bocher P (2017) Low benthic macrofauna diversity in dynamic tropical tidal mudflats: migrating banks on Guiana's coast, South America. Estuar Coast 40: 1159-1170

Kanou K, Sano M, Kohno H (2005) Ontogenic diet shift, feeding rhythm, and daily ration of juvenile yellowfin goby Acanthogobius flavimanus on a tidal mudflat in the Tama River estuary, central Japan. Ichtyol Res 52: 319-324

Kneib RT (1985) Predation and disturbance by grass shrimp, Palaemonaetes pugio, Holthuis, in soft-substratum invertebrate benthic assemblages. J Exp Mar Biol Ecol 93: 91-102

Kovačić M, la Mesa M (2008) Feeding ecology of De Buen's goby Buenia affinis, in the Kvarner area (Adriatic Sea). Vie Milieu 58: 249-256

Krebs JR (1978) Optimal foraging: decision rules for predators. In: Krebs JR, Davies NB (eds) Behavioural ecology, an evolutionary approach. Blackwell, Oxford

Leduc D, Probert PK, Duncan A (2009) A multi-method approach for identifying meiofaunal trophic connections. Mar Ecol Prog Ser 383: 95-111

Legrand E, Martin S, Leroux C, Riera P (2018) Effect of temperature on an algal-grazer trophic transfer: a dual stable isotope $\left({ }^{13} \mathrm{C},{ }_{1}{ }^{5} \mathrm{~N}\right)$ labeling experiment. Mar Ecol 39: e12495

Leroy F, Riera P, Jeanthon C, Edmond F, Leroux C, Comtet T (2012) Importance of bacterivory and preferential selection toward diatoms in larvae of Crepidula fornicata (L.) assessed by a dual stable isotope $\left({ }^{13} \mathrm{C},{ }_{15} \mathrm{~N}\right)$ labeling approach. J Sea Res 70: 23-31 
Li J, Vincx M, Herman PMJ (1996) A model of nematode dynamics in the Westerschelde Estuary. Ecological Modelling 90: 271-284

Lipcius RN, Hines AH (1986) Variable functional responses of a marine predator in dissimilar homogeneous microhabitats. Ecology 67: 1361-1371

Majdi N, Hette-Tronquart N, Auclair E, Bec A, Chouvelon T, Cognie B, Danger M, Decottignies P, Dessier A, Desvilettes C, Dubois S, Dupuy C, Fritsch C, Gaucherel C, Hedde M, Jabot F, Lefebvre S, Marzloff MP, Pey B, Peyrard N, Powolny T, Sabbadin R, Thébault E, Perga ME (2018) There's no harm in having too much: a comprehensive toolbox of methods in trophic ecology. Food Webs 16: e00100

McCall JN, Fleeger JW (1995) Predation by juvenile fish on hyperbenthic meiofauna: a review with data on post-larval Leiostomus xanthurus. Vie Milieu 45: 61-73

Middelburg JJ, Barranguet C, Boschker HTS, Herman PMJ, Moens T, Heip CHR (2000) The fate of intertidal microphytobenthos carbon. An in situ 13C labelling study. Limnol Oceanogr 45: $1224-1234$

Moens T, Braeckman U, Derycke S, Fonseca G, Gallucci F, Gingold R, Guilini K, Ingels J, Leduc D, Vanaverbeke J, Van Colen C (2013) Ecology of free-living marine nematode. In: SchmidtRhaesa A (ed) Handbook of zoology: gastrotricha, cycloneuralia and gnathifera, Berlin, pp 109-152

Moens T, Luyten C, Middelburg JJ, Herman PMJ, Vincx M (2002) Tracing organic matter sources of estuarine tidal flat nematodes with stable carbon isotopes. Mar Ecol Prog Ser 234: 127137

Moodley L, Middelburg JJ, Boschker HTS, Duineveld R, Pel R, Herman PMJ, Heip CHR (2002) Bacteria and foraminifera: key players in a short-term deep sea benthic response to phytodetritus. Mar Ecol Prog Ser 236: 23-29

Nguyen HT, Dupuy C, Jourde J, Lefrançois C, Pascal PY, Carpentier A, Chevalier J, Bocher P (2018) Persistent benthic communities in the extreme dynamic intertidal mudflats of Amazonian coast: An overview of the Tanaidacea (Crustacea, Peracarida). Mar Biodiv 48: 1841-1853

Nilsson P, Sundback K, Jonsson B (1993) Effect of the brown shrimp Crangon crangon on endobenthic macrofauna, meiofauna and meiofaunal grazing rates. Neth J Sea Res 31: 95-106

O'Gorman EJ, Enright RA, Emmerson MC (2008) Predator diversity enhances secondary production and decrease likelihood of trophic cascades. Oecologia 158: 557-567

Ólafsson E (2003) Do macrofauna structure meiofauna assemblages in marine soft-bottoms? Vie Milieu 53: 249-265

Ólafsson E, Elmgren R, Papakosta O (1993) Effects of the deposit-feeding benthic bivalve Macoma balthica on meiobenthos. Oecologia 93: 457-462

Pascal PY, Dupuy C, Haubois AG, Richard P, Niquil N (2008a) Influence of environment factors 
on bacterial ingestion rate of the deposit-feeder Hydrobia ulvae and comparison with meiofauna. J Sea Res 60: 151-156

Pascal PY, Dupuy C, Mallet C, Richard P, Niquil N (2008b) Bacterivory by benthic organism in sediment: quantification usingis $\mathrm{N}$-enriched bacteria. J Exp Mar Biol Ecol 355: 18-26

Pascal PY, Dupuy C, Richard P, Mallet C, Armynot du Chatelet E, Niquil N (2009) Seasonal variation in consumption of benthic bacteria by meio- and macrofauna in an intertidal mudflat. Limnol Oceanogr 54: 1048-1059

Pascal PY, Dupuy C, Richard P, Rzeznik-Orignac J, Niquil N (2008c) Bacterivory of a mudflat nematode community under different environmental conditions. Mar Biol 154: 671-682

Pascal PY, Fleeger JW (2013) Diverse dietary responses by saltmarsh consumers to chronic nutrient enrichment. Estuar Coast 36: 1115-1124

Peters RH (1983) The ecological implication of body size. Cambridge University Press

Pihl L, Rosenberg R (1984) Food selection and consumption of the shrimp Crangon crangon in some shallow marine areas in western Sweden. Mar Ecol Prog Ser 15: 159-168

Reise K (1978) Experiments on epibenthic predation in the Wadden Sea. Helgol Wiss Meeresunters 31: 55-101

Ryer CH (1987) Temporal patterns of feeding by blue crabs (Callinectes sapidus) in a tidalmarsh creek and adjacent seagrass meadow in the lower Chesapeake Bay. Estuaries 10: $136-140$

Scherer B, Reise K (1981) Significant predation on micro- and macrobenthos by the crab Carcinus maenas L. in the Wadden Sea Kieler Meeresforsch, pp 490-500

Scholz DS, Matthews LL, Feller RJ (1991) Detecting selective digestion of meiobenthic prey in juvenile spot Leiostomus xanthurus (Pisces) using immunoassays. Mar Ecol Prog Ser 72: $59-67$

Schratzberger M, Ingels J (2018) Meiofauna matters: the role of meiofauna in benthic ecosystems. J Exp Mar Biol Ecol 502: 12-25

Schratzberger M, Warwick JT (1999) Differential effects of various type of disturbances on the structure of nematode assemblages: an experimental approach. Mar Ecol Prog Ser 181: 227-236

Schückel S, Sell AF, Kihara TC, Koeppen A, Kröncke I, Reiss H (2013) Meiofauna as food source for small-sized demersal fish in the southern North Sea. Helgol Mar Res 67: 203-218

Schwinghamer P, Hargrave BT, Peer D, Hawkins CM (1986) Partitioning of production and respiration among size groups of organisms in an intertidal benthic community. Mar Ecol Prog Ser 31: 151-166

Serrano A (2012) Changes in gut evacuation time for larval mud crab, Scylla serrata (Crustacea: Portunidae) fed artificial or live food. AACL Bioflux 5: 240-248

Shaw M, Jenkins GP (1992) Spatial variation in feeding, prey distribution and food limitation of juvenile flounder Rhombosolea tapirina Günther. J Exp Mar Biol Ecol 165: 1-21 
682 van Oevelen D, Moodley L, Soetaert K, Middelburg JJ (2006) The trophic significance of 683 bacterial carbon in a marine intertidal sediment: Results of an in situ stable isotope 684 labeling study. Limnol Oceanogr 51: 2349-2359

685

686

687 